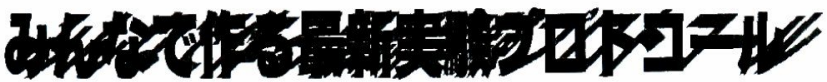

\section{加水分解酵素を用いる鏡像体の分離 一選択性の評価，実施上の注意}

黒川 真行, 須貝 威 慶應義塾大学理工学部

1.はじめに

有機化合物中の炭素原子にすべて異なるものが結合して いる場合，その原子は「不斉炭素（ふせいたんそ）」と呼ば れ，鏡に映した一対の「鏡像異性体」が生じる (図 1)。こ の異性体は「光学異性体」とむ呼ばれ, 医薬・農薬などと して生物に作用した際，一方の鏡像異性体は目的とする薬 理作用を示すのに対し, 他方の鏡像異性体が重篤な副作用 や，予想外の活性を示すことがしばしば見いだされてき た ${ }^{1)}$. 鏡像体 A, B は, 光学的性質を除いた物理化学的挙動 が全く同一であり，分離することは容易でない，鏡像異性 体の片方を選択的に作り出す「不斉合成」の技術の一つと して, Sharpless の不斉ジヒドロキシル化を本誌 76 巻 9 号に石川らが紹介したが，両鏡像体を分離し（「光学分割」 という)，純粋な異性体として供することもまた重要な技 術である。「純粋な」鏡像異性体を,「光学活性体」という が,「純粋さ」の程度は,「鏡像体過剩率 (enantiomeric excess, e.e.)」という尺度で表される．両鏡像体の当量混合物 は,「ラセミ体」と呼ばれ，鏡像体過剩率は，50\%-50\%= 0\%である.これに対し, 鏡像体 A と鏡像体 B が $97: 3$ で 存在するようなむのは, $97 \%-3 \%=94 \%$ e.e. と表される.

\section{2. 速度論的光学分割}

さて, 酵素触媒反応は, タンパク質の中に巧妙に配置さ れた複数の「アミノ酸」の，共同作用によって起こってい る. 一対の鏡像体分子がタンパク質の中に「反応基質」と

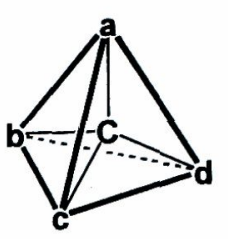

踥像䔬性体 A

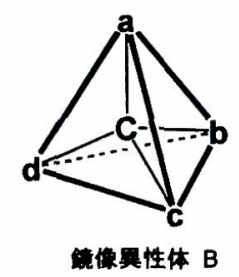

図 1
して取り込こまれる際, 酵素との親和性 $\left(K_{\mathrm{m}}\right)$, 触媒反応の 速度 $\left(k_{\mathrm{cat}}\right)$ が異なるケースが生じる. 両鏡像体 $\mathrm{A}, \mathrm{B}$ 間にお ける反応速度 $\left(v_{\mathrm{A}}, v_{\mathrm{B}}\right)$ の比は, $k_{\mathrm{cat}} / K_{\mathrm{m}}$ およびそれぞれの基 質濃度 ([A], [B]) によって (1)のように表されるが，これを (2) のように変形することができる，この (2)の中で, 両鏡 像体の $k_{\text {cat }} / K_{\mathrm{m}}$ の比をとった值を, 鏡像体選択率 (enantiomeric ratio, $E$ value) と言い, この值が大きいほど, 分 離の「切れ味」がよい (式 (1)).

式 (2)のように, 同一の容器内, 鏡像異性体が共存する 状態で同一の酵素が作用した場合, $k_{\mathrm{cat}} / K_{\mathrm{m}}$ が一方の鏡像 異性体で非常に大きく（触媒作用が非常に円滑に進行す る), 他方の鏡像体では非常に小さい（酵素が㗢かない）場 合には，鏡像体 A, B の混合物加ら出発すると，反応の終 了時には, 未反応回収原料 $\mathrm{B}$ と, 生成物 $\mathrm{P}$ が生じる. 反応 終了時の未反応回収原料 $\mathrm{B}$ と, 生成物 $\mathrm{P}$ は異種の物質で あり, 分離精製可能である.このように, 鏡像体 A, B に対 して何らかの反応をほどこし, 反応速度の違いによって, 未反応回収原料 $\mathrm{B}$ と, 生成物 $\mathrm{P}$ とて, 結果的に鏡像体 $\mathrm{A}$ を分離することを「速度論的光学分割」と呼ぶ、例えば, エステルを加水分解する酵素を用いた場合, カルボン酸部 分の不斉炭素を認識し, 光学活性なカルボン酸が得られる

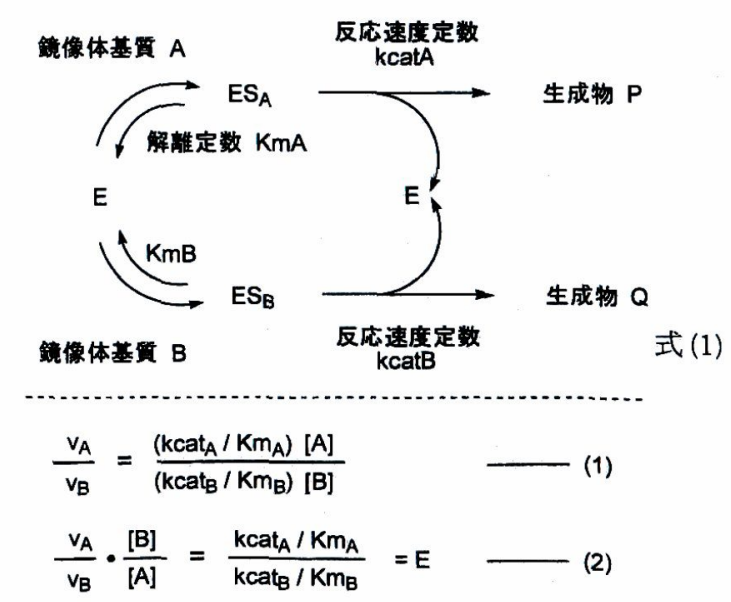




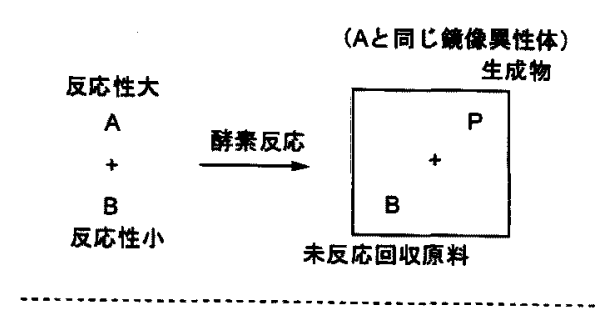

カルボン醩の光学分割
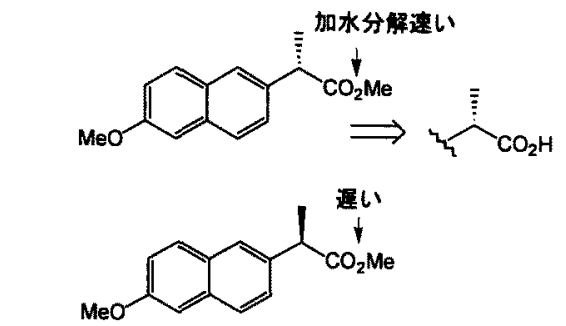

式 (2)

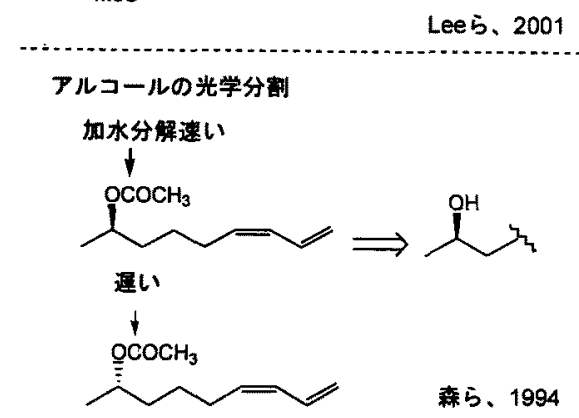

ケースよ，アルコール部分の立体化学を見分けるケースが

知られている。この手法は，コウジカビのアミノアシラー ゼを用いたアミノ酸類の純粋な鏡像体の工業的製造法など に応用されている、二つの鏡像体が完全に分離できるの

は，鏡像体選択比 $E$ 值が無限大に近い場合である.

（1）鏡像体選択性の評価一純粋な鏡像体間における反応 速度比較

標的とする化合物を速度論的に分割するには，さまざま な酵素を探索(スクリーニング）し，それぞれの $E$ 值を評 価，選抜するという作業が不可欠である，Kazlauskasは， Quick E と呼ばれる方法を確立した，まず，基質のカルボ ン酸部位を $p$-ニトロフェニルエステルとしたものを準備 し，ここに基準物質としてレゾルフィンエステルを加え， これに酵素を作用させる、ここで，基質は純粋な鏡像体で ある，基質と基準物質の加水分解によって生じるフェノキ シドは，それぞれ $404 \mathrm{~nm}, 572 \mathrm{~nm}$ に吸収波長をもつの で、これらの吸光度を測定することによって，基準物質に 対する基質（鏡像体 A）の相対的な反応性が評価できる [式 (3)，(3) および (4)]. 次に，基質 B に対して手同じ測定 を行う。このようにして得た両鏡像体 $\mathrm{A}, \mathrm{B}$ それぞれの相 対的反応性を割り算することにより，(2)に従って鏡像体 選択比 $E$ 值が計算される.

この場合，スクリーニングに使う基質に， p-ニトロフェ
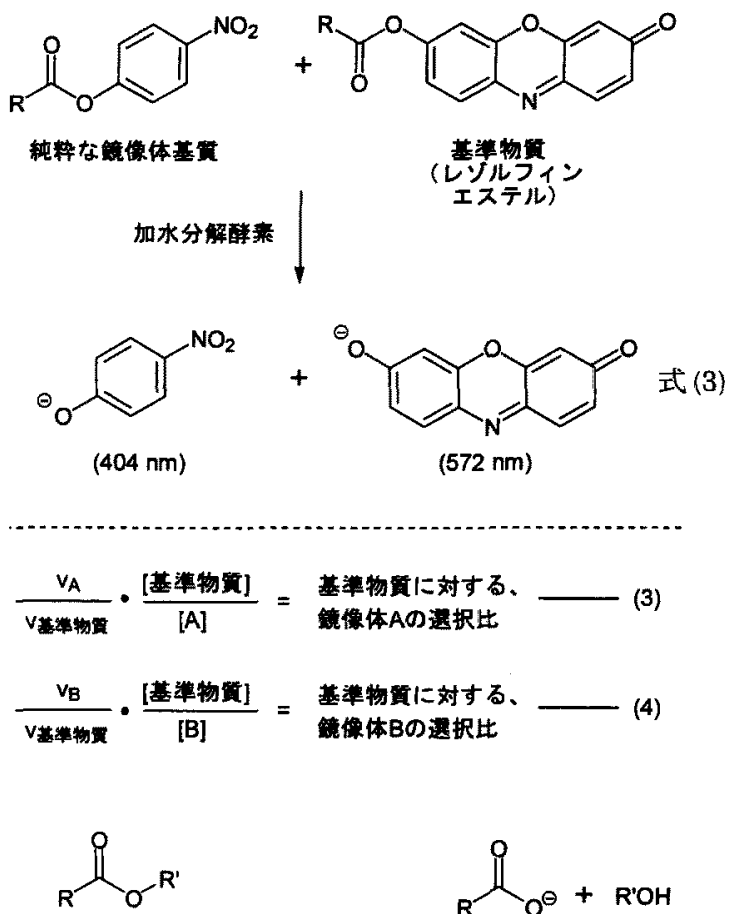

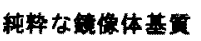

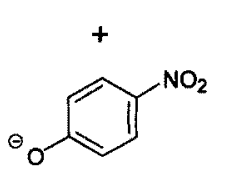

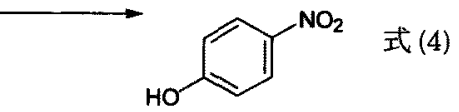

(404 nm)

プロトン化され、吸光度娍少

ノールをエステルとして導入する必要があり，エステルの アルコール部分に不斉炭素が含まれ，そちらの方が必要な 化合物には，適用することができない，Kazlauskas らは， この手法を，一般的なエステル類に拡張すべく検討を重 栘, 以下の方法を開発した。 あらかじめ中性の反応系内に $p$-ニトロフェノール $\left(\mathrm{p} K_{\mathrm{a}}=7.2\right)$ を添加しておくと, 当初フ ェノキシドとして $404 \mathrm{~nm}$ に吸収を有するが, 酵素加水分 解で生じたカルボン酸に相当する量のフェノキシドがプロ トン化され，吸光度が減少する（式 (4)）。この変化を測定 することにより，反応初速が定量的に観测できる2)。この 際，緩衝溶液として BES $\left(\mathrm{p} K_{\mathrm{a}}=7.15\right)$ を用いる，この検定 法は，両鏡像体の反応初速の差を容易に比較することがで きるので，多数の酵素サンプルの比較選抜に適した方法で ある，さらに，式(3) と式(4)の方法を組合せ，さまざまな 基質に対する加水分解䣲素の選択性を迅速に検証できるよ うになった。

（2）镜像体選択性の評価一endpoint 法

しかし，上のように純粋な鏡像体の基質が常に得られる とは限らず，むしろラセミ体のみしか入手できないことが 多い. Sih らは，先に述べた $E$ 值，そして反応の進行度 (転 換率, conversion）を，反応後に生じた生成物の鏡像体過 


$$
\begin{aligned}
& E=\frac{\ln [(1-c)(1-\theta . e .(\mathrm{S}))]}{\ln [(1-c)(1+e . e .(\mathrm{S}))]}=\frac{\ln [1-c(1+e . e .(\mathrm{P}))]}{\ln [1-c(1-\theta . e .(\mathrm{P}))]}-(5) \\
& \text { conv. }(\%)=\frac{\theta . e .(\mathrm{S})}{\text { e.e.(S)+e.e.(P)} \times 100} \text { 式 (5) }
\end{aligned}
$$

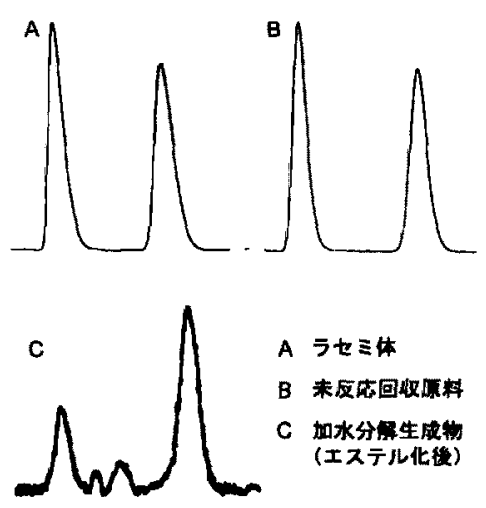

国 2

剩率 $[$ e.e. $(\mathrm{P})]$ 之, 未反応原料の鏡像体過剩率 $[e . e .(\mathrm{S})]$ 加ら 計算する方法を案出した $[\text { 式(5)，(5) 拈よび(6) }]^{3)}$. これを endpoint 法という. 両鏡像体の過剩率は, キラルな固定相 を有する HPLC や GCによる直接的分析方法（本誌 76 巻 12 号に，ダイセルのグループにより執筆予定）が精力的に 研究され，大きく発展を遂げたので，この方法は飛躍的に 精度が高くなった。

これによれば，反応後に回収した未反应料上生成物の 鏡像体比率がそれぞれ分析できれば，必ず選択性評価が可 能になるが，デー夕の盲信は危険である，筆者らのグルー プで遭遇した例を参考に警鐘したい。ここに示した三つの LCチャートのうち，A はラセミ体の分析結果であり，鏡 像体は明確に分離している。この基質に酵素反応を試みた が，反応性が非常に低く，ほとんど進行していなかった。 Bに未反応回收原料のチャートを示すが，ここからe.e.(S) は 4.4\% 上算出される. しかしこのようにラセミ体に非常 に近い場合，ベースラインのわずかな変動によって大きく 影響を受けてしまう。一万，Cは反応生成物の分析結果で あるが，反応の進行度が小さいため，当然得られたサンプ ルも微量で, チャ一トのS $/ N$ が極端に低下している. 不純 物のピークが目的物近傍に混入しているうえ, サンプルが 微量なため, co-injectionによる同定も，単純な検出シス テムでは困難である。このようなとき，実験者はしばしば e.e.の決定を大き目に見積もってしまいがちになり（特に 研究監督者の要求が㛜しい場含), さらに対数計算プロセ スが加わるので $E$ 值は非常に大きく誇張されてしまう。精 度よい分析，先入観や期待にとらわれないピークの同定が 不可欠であり，多チャンネルフォトダイオードアレイ検出

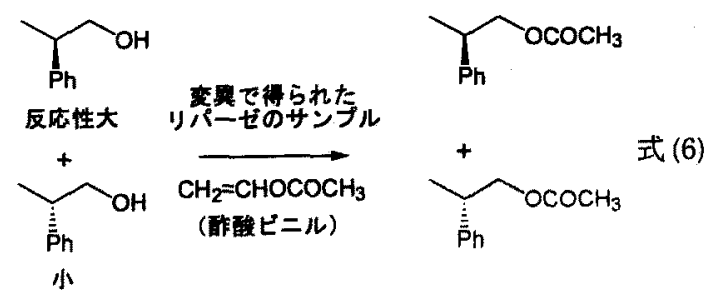

器による多波長分析などは非常に有効な手法である。

もし，反応系からサンプリングするのみで，末反応原料 と生成物を単離することなく，鏡像体過剩率や転換率が簡 便に算出できるようになれば，多数の醉素サンプルからス クリーニングするような場合, 自動化分析す可能である.

実際, Reetz らは, Pseudomonas aeruginosa リパーゼの野 生型から出発し, 進化工学的手法により得た多数の酵素サ ンプルを調製し，この酵素が触媒する鏡像体選択的アシル 化（式(6)）の選択性評価に，自動分析を用いている4). マイ クロプレート上の 96 むしくは 384 穴で同時に多数の反応 を行い,ここからコンピューター制御のあと，キラルな固 定相を用いた GCにて順次迅速に分析した，基質であるア ルコールの雨鏡像体は二つのピークに分離し, 一方, 生成 物であるアセタートの雨鏡像体は分離しない．アルコール とアセタートの面積比から転換率 $(c)$ を，末反応両鏡像体 の面積比からe.e.(S) を求め, 前述の (5) にて $E$ 值を計算し た. 野生型では鏡像体選抧性をはとんど示さない醳素 $(E=$ 1.1) 加ら，E値を 25 前後まで向上させたものを数世代の 変異で得ることに成功している.

ここで注目すべきことは，酵素によって触媒される反応 が有機溶媒中のアシル化という, 酵素タンパク質の固体を 除けば，反応系が均一な，やや特殊な条件である。このよ うな分析法は，エステルの加水分解のように，不均一系や 二相系で反応を行っているようなケースに適用することは 難しい. 仮に少量を抽出するとしても, 基質と生成物で水一 有機溶媒への分配係数が異なる場合には，正確に転換率を 決定することができない，このような場合は，一度のサン プル注入で，未反応原料も生成物も同時に鏡像体分析が可 能な分析条件が要求される。

\section{3. 酵素による速度論的分割: 実施上のトラブルと解 決}

以上に述べた速度論的分割の試剤として，リパーゼやプ ロテアーゼなどの加水分解醉素が，天野エンザイム（本誌 76 巻 11 号に執筆予定), 東洋紡, 長瀬産業, 生化学工業, 名糖産業, Sigma, Boehringerなどから市販されている. 試薬しして比較的安定な粉末が多く，冷蔵庫内で長期保存 することが可能であり，有機合成の試薬レベルで取り扱う 


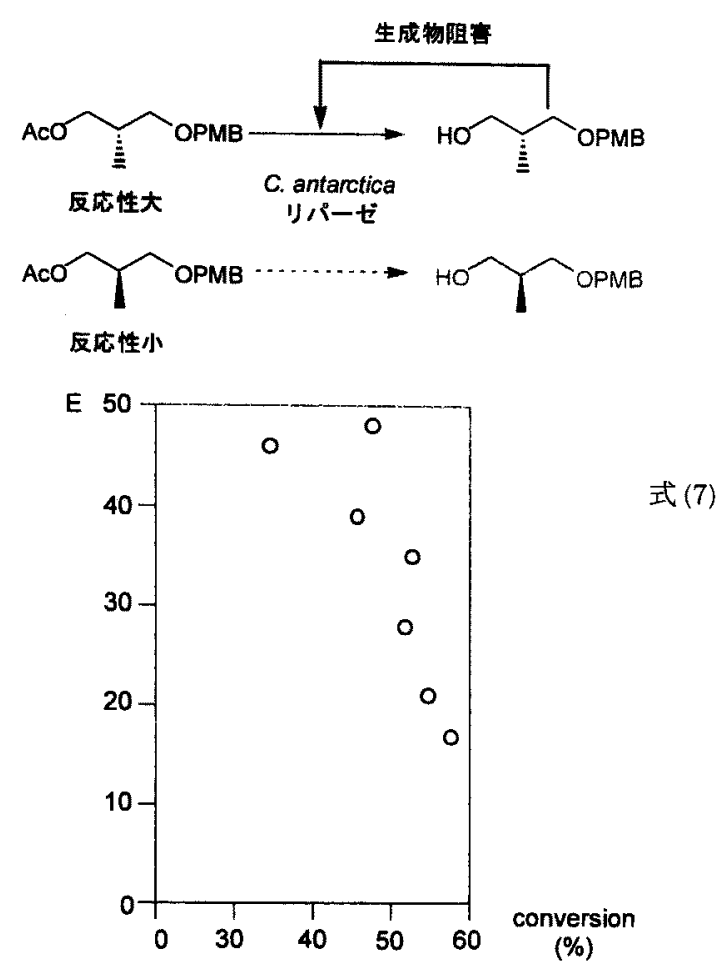

ことができる. 分割の成功例は多数報告されているが，こ こでは，筆者らが経験した手強いトラブルの例とその解決 法について紹介する.

(1) 生成物阻害によって, 反応が完結しなくなるケース 速度論的分割の達成には，酵素が失活することなく，優 先鏡像体の反応が完結することが不可欠である。式 (7)に 示すラセミ体アセタートに対し, 速度論的光学分割を検討 したところ,Candida antarctica 由来のリパーゼを用いた 加水分解が，鏡像体選択的に進行することを見いだした. ところが， $E$ 值は転換率の上昇に伴い，明ら加に低下し (60\% conv., E 15), 未反応原料の鏡像体過剩率が頭打ちに なってしまった。これは，反応の進行に伴って蓄積するア ルコールが, より反応性の高い鏡像体のアセタートの加水 分解を阻害するためであることがわかった（式(7)). 60\% conv.の時点で, 醭素活性は初期值の $55 \%$ にまで低下す る.このトラブルの回避には，ある程度加水分解を進行さ せた段階で反応を停止し，系内で生じている，阻害作用を あつアルコールを分離除去, 再び末反応アセタートを反応 に供するという方法が有効であっだ．これにより，99.2\% e.e. の $(R)$-アセタートが, 収率 $42 \%$ で得られるようになっ た。二度に分けた場合，E值はそれぞれ，28(1st), 40 (2nd) であった.

（2）ラセミ体の基質が, 純粋な鏡像体と比較して結晶性が 高いケース

医薬品中間体，不斉合成誘導試剤として有用なアミノア
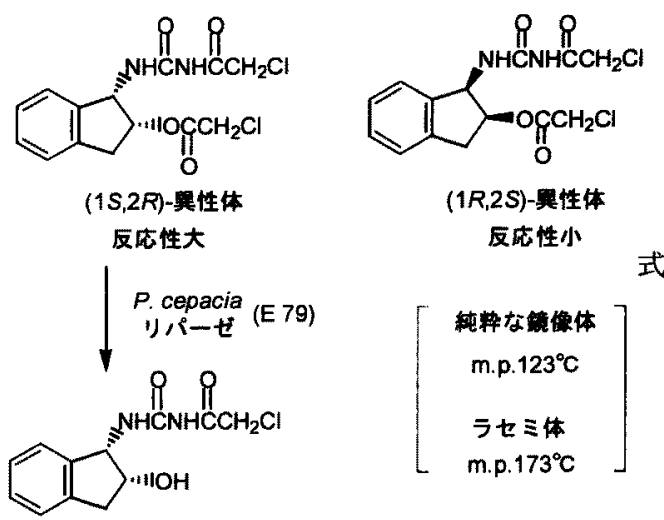

式 (8)

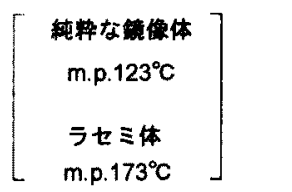

ルコール (式 (8)) をラセミ体の酵素分割で得ようとして, まず，クロロアセチル体の雨鏡像体を合成し，種々のリ パーゼによって加水分解速度を比較した，反応追跡は TLC 分析にて定性的に行い, Pseudomonas cepacia リ パーゼを $(1 S, 2 R)$-鏡像体を優先的に加水分解する醉素亡 して選抜した，ところが，実際にラセミ体の光学分割を試 みたところ，反応はほとんど進まなかった，両鏡像体間の 速度の比較を利用して，選択性の高い酵素の選抜に成功し たのにむかかわらず，分割に適用できなかったケースであ る. 原因を詳細に検討したところ，基質の純粋な鏡像体と ラセミ体では結晶構造, 特に分子間水素結合の様式が大き く異なり，その結果ラセミ体の融点が $50^{\circ} \mathrm{C}$ 高く, かつ溶 解性が非常に低いために酵素反応が起こりにくいというこ とが判明した。この問題は，水系反応媒体への有機溶媒 (ここではアセトン) の添加による, 基質の溶解度向上によ って解決し, 光学分割に成功した6).この際に固定化は, 酵 素の有機溶媒利性を高め, 反応促進に有効であった.

\section{4.おわりに}

純粋な鏡像体の調製に，加水分解酵素を用いる利点，評 価方法や注意点について述べてきた．加水分解酵素を用い る速度論的光学分割においてもう一つの重要な方法, 有機 溶媒中のアシル化（加水分解の逆反応）については, 紙面 の都合上割愛し別稿に記述した7)、いずれにせよ，活性お よび選択性の高い酵素の開発と並んで, 合成上有用, かつ 酵素反応にも「相性のよい」化合物の設計が重要である.

1) 新開一郎監修:「キラル医薬中間体のプロセス技術一開発・ 製造とアウトソーシングの動向」，技術情報社，2001．

2) R. J. Kazlauskas et al.: Tetrahedron: Asymmetry, 12, 545556 (2001).

3) C. J. Sih et al: J. Am. Chem. Soc., 104, 7294-7299 (1982).

4) M. T. Reetz: Angew. Chem. Int. Ed., 40, 284-310 (2001).

5) T. Sugai et al.: Adv. Synth. Catal., 343, 624-637 (2001).

6) T. Sugai et al:: Tetrahedron, 57, 4841-4848 (2001).

7) 須貝ら,ファルマシア, 揭載予定. 